\title{
ANALISIS KETERCAPAIAN INDIKATOR STANDAR PROSES PADA MA ADDZURIYATUS SHOLIHIN
}

\author{
Sinta Nurhayati ${ }^{1}$,Leni Redha ${ }^{2}$, Lastia Laksana ${ }^{3}$ \\ ${ }^{1}$ Program Pascasarjana UIN Sunan Gunung Djati Bandung, Jl. A. H \\ Nasution 105 Bandung, Jawa Barat, Indonesia, email: \\ Sintahayati01@gmail.com \\ ${ }^{2}$ Program Pascasarjana UIN Sunan Gunung Djati Bandung, Jl. A. H \\ Nasution 105 Bandung, Jawa Barat, Indonesia, email : \\ leniredha.fidkom@gmail.com \\ ${ }^{3}$ Program Pascasarjana UIN Sunan Gunung Djati Bandung, Jl. A. H \\ Nasution 105 Bandung, Jawa Barat, Indonesia, email : \\ laksanalastia@gmail.com
}

\begin{abstract}
This article aims to determine the standard of the research process at MA Adzuriyatus Solihin ciparay Bandung. This research is a qualitative research by collecting data in the form of observation, interviews and documentation. The results of this study indicate that the achievement of process standards at MA Adzuriyatus Solihin Ciparay Bandung is $91.42 \%$ when compared to the entire maximum score that should be achieved in the standard process. This study recommends in-depth. indicators that have not been achieved optimally, especially school indicators carry out the learning process with a maximum of 36 students in the study group and the teacher conducts good classroom management with 12 criteria. According to the author, the principal must conduct an evaluation and supervision of the way to teach in the class, also conduct training for teachers who have not been able to achieve standard process indicators. Because in learning the class of educators plays an important role in the learning process. This is intended to improve the quality of education and satisfaction of community expectations.
\end{abstract}

Keynotes: process standards, educators, students

\begin{abstract}
ABSTRAK
Artikel ini bertujuan untuk mengetahui standar proses penelitian di MA Adzuriyatus Solihin ciparay Bandung. Penelitian ini merupakan penelitian kualitatif dengan pengumpulan data berupa observasi, wawancara dan dokumentasi. Adapun hasil penelitian ini menunjukan bahwa pencapaian standar proses di MA Adzuriyatus Solihin ciparay Bandung 91,42\% jika disbanding dengan seluruh skor maksimum yang seharusnya dicapai pada borang standar proses. Penelitian ini merekomendasikan untuk
\end{abstract}


mendalam. Indikator-indikator yang belum tercapai dengan optimal, khususnya indikator sekolah melakukan proses pembelajaran dengan jumlah siswa perombongan belajar maksimum 36 orang dan guru melakukan pengelolaan kelas yang baik dengan 12 kriteria. Menurut penulis, kepala sekolah harus melakukan evaluasi dan supervisi terhadap cara mengajar di kelas, juga melakukan pelatihan-pelatihan terhadap guru yang belum mampu mencapai indikator standar proses. Karena dalam pembelajaran di kelas pendidik sangat berperan penting dalam proses pembelajaran. Hal ini dimaksudkan untuk meningkatkan mutu pendidikan dan pemuasan harapan masyarakat.

Kata kunci : standar proses, pendidik, peserta didik.

\section{PENDAHULUAN}

Standar Nasional Pendidikan merupakan acuan utama yang mengatur tentang standar minimal yang harus terpenuhi dalam pengelolaan sekolah oleh segenap penyelenggara sekolah, yaitu guru dan kepala sekolah. Tuntutan profesionalisme seorang guru tidak hanya dari pihak pemerintah saja, melainkan juga diminta oleh pihak masyarakat yang memanfaatkan tenaga guru dalam membimbing, mengajar, dan mendidik peserta didik. Alasannya tanpa adanya profesionalisme guru maka akan sangat mustahil siswa dapat mencapai kualitas hasil belajar yang maksimal. Tentunya perlu secara seksama kita lakukan peninjauan kembali kepada Undang-Undang Nomor 20 Tahun 2003 Tentang Sistem Pendidikan Nasional dan Peraturan Pemerintah Nomor 19 Tahun 2005 Tentang Standar Nasional Pendidikan.

Kondisi saling lempar tanggung jawab ini yang terpantau oleh pemerintah pusat, sehingga diterbitkanlah Peraturan Pemerintah Nomor 19 Tahun 2005 tentang Standar Nasional Pendidikan dan Undang-undang Sistem Pendidikan Nasional mengisyaratkan agar sekolah menerapkan Manajemen Pendidikan Berbasis Sekolah yang sering dikenal dengan MBS. Penerapan MBS ini haruslah memenuhi 8 (delapan) standar nasional pendidikan (SNP), yakni: 1) standar isi; 2) standar proses; 3) standar kompetensi lulusan; 4) standar pendidik dan tenaga kependidikkan; 5) standar sarana dan prasarana; 6) standar pengelolaan; 7) standar pembiayaan; 8) standar penilaian pendidikan.

Hakekatnya, pengaturan standar pendidikan dimaksudkan untuk memastikan setiap lembaga pendidikan memiliki kelayakan sebagai lembaga yang memberikan pelayanan yang optimal. Sehingga setiap lembaga pendidikan wajib memiliki semua layanan dengan mengacu kepada delapan standar nasional 
pendidikan. Karena standar tersebut berfungsi sebagai dasar dalam perencanaan, pelaksanaan, dan pengawasan pendidikan dalam rangka mewujudkan pendidikan nasional yang bermutu.

Dari 8 standar tersebut sangat penting dan memiliki keterkaitan satu sama lain dalam pencapaian mutu sekolah dan seterusnya dapat tercapai pula tujuan pendidikan yang diharapkan. Namun demikian, standar proses merupakan jantung dalam sistem pendidikan. Idealnya standar kompetensi lulusan yang baik serta lengkapnya standar isi yang ditetapkan, namun tanpa implementasi ke dalam proses pendidikan, maka semua tidak akan berarti apa-apa (Sanjaya 2014:10).

Standar proses memiliki 4 komponen yang harus dipenuhi, yaitu perencanaan pembelajaran, penilaian hasil belajar dan pengawasan proses pembelajaran.

Standar proses merupakan variabel yang perlu diperhatikan untuk dapat menghasilkan output yang memiliki kualitas kompetitif. Maka dari itu sangat diperlukan terjadinya suatu proses pendidikan atau pembelajaran yang optimal. Untuk menjadikan proses pembelajaran tersebut optimal, diperlukan berbagai usaha untuk perbaikan dan peningkatan, termasuk dengan melakukan penjaminan mutu proses pembelajaran.

\section{METODE PENELITIAN}

Metode ini dilakukan di MA Addzuriyatus Sholihin. Metode yang digunakan dalam penelitian ini adalah metode deskriptif dengan pendekatan kualitatif. Azwar (2012: 5) mengemukakan pendekatan kuantitatif menekankan analisisnya pada data-data numerical (angka) yang diolah dengan metode statistika.

Penelitian deskriptif bertujuan menggambarkan secara sistematik dan akurat fakta dan karakteristik mengenai populasi atau bidang tertentu ( Azwar, 2012: 7). Sampel yang digunakan untuk penelitian adalah guru produktif dan Kepala sekolah di MA Addzuriyatus Sholihin ciparay. Aspek yang dimaksud dalam penelitian adalah guru analisis pelaksanaan standar proses pada sekolah MA Addzuriyatus Sholihin. Faktor yang diteliti meliputi faktor internal, terdiri dari atas pengetahuan dan kesiapan guru dalam perencanaan pembelajaran, pengelolaan kelas oleh guru dalam mengimplementasikan perencanaan, Penilaian proses pembelajaran dan faktor eksternal terdiri atas pengawasan 
kepala sekolah. Teknik pengumpulan data menggunakan metode observasi, wawancara dan dokumentasi. Instrumen yang digunakan adalah lembar atau chek list yang digunakan untuk memahami masalah pengumpulan data dalam penelitian dan untuk mengetahui tolak ukur penilaian. Instrument lain yang digunakan adalah wawancara berkaitan dengan 21 indikator standar proses kepada pendidik dan tenaga kependidikkan di sekolah. Analisis data hasil observasi dilakukan dengan cara mengkomplikasi dan menginterprestasikan secara kualitatif. Analisis data hasil wawancara diberi skor sehingga diperoleh skor total yang menunjukkan tingkat ketercapaian indikator-indikator pada standar proses. Analisis pengumpulan dokumen untuk melengkapi hasil pengelolaan data observasi dan wawancara. Hasil analisis data secara keseluruhan akan dijadikan bahan untuk penyusun kesimpulan dan rekomendasi. analisis yang digunakan untuk mengetahui tingkat kesenjangan pelaksanaan standar proses di sekolah menggunakan analisis deskriptif prosentase, kemudian diubah kedalam kalimat yang bersifat kualitatif untuk menentukan kategori pencapaian indicator dalam standar proses.

Berdasarkan hasil wawancara yang dilakukan pada kepala sekolah MA Adzuriyatus Solihin mengenai jumlah siswa di kelas mencapai 20 orang per kelas belum mencapai 36 orang setiap kelasnya dikarenakan sekolah yang masih baru didirikan dan baru pertama kali melaksanakan akreditasi pada tahun 2019 ini. Adapun beberapa guru yang belum melakukan pengelolaan kelas yang baik dengan 12 kriteria dalam hal pengaturan suara dan tempat yaitu Kesulitannya yaitu dalam mengatur intonasi ketika memberi penjelasan, dikarenakan masih ada guru yang kadang belum siap atau memahami betul RPP dan materi akhirnya terkesan tidak pas ketika menyampaikan. Selain itu dalam pengaturan tempat duduk siswa, cenderung statis tidak berubah-ubah posisi Sehingga terkesan pasif tidak aktif dalam mengelola kelas. Adapun Bagaimana Rencana Untuk mengatasi hal tersebut kepala sekolah membuat rencana supervisi akademik Langkahlangkah: (1) Perencanaan dengan mengidentifikasi permasalahan yang terjadi. (2)Mengumpulkan data dengan kunjungan ketika guru bersangkutan mengajar atau pertemuan khusus dengan guru bersangkutan. (3)Memberikan pembinaan guru dan sharing tentang pembelajaran yang efektif dan lebih baik. (4) Evaluasi dari hasil pelaksanaan supervisi yang dilakukan kepala sekolah. (5) tindak lanjut. Adapun pelaksanaan dilaksanakan minimal setiap 1 semester sekali. 


\section{HASIL DAN PEMBAHASAN}

Berdasakan hasil pengambilan dan analisis data tentang ketercapaian indikator pada Standar Proses pada MA Addzuriyatus Sholihin Ciparay maka dapat disajikan profil ketercapaian indicator Standar Proses, Distribusi Indikator Stndar Proses, dan masalah serta tindak lanjut perbaikan capaian indikator Standar Proses.

\section{Profil Ketercapaian Indikator Standar Proses}

Profil ketercapaian indikator standar proses pada MA Adzuriyatus Solihin Ciparay dapat ditunjukkan dengan grafik pada gambar 1 berikut.

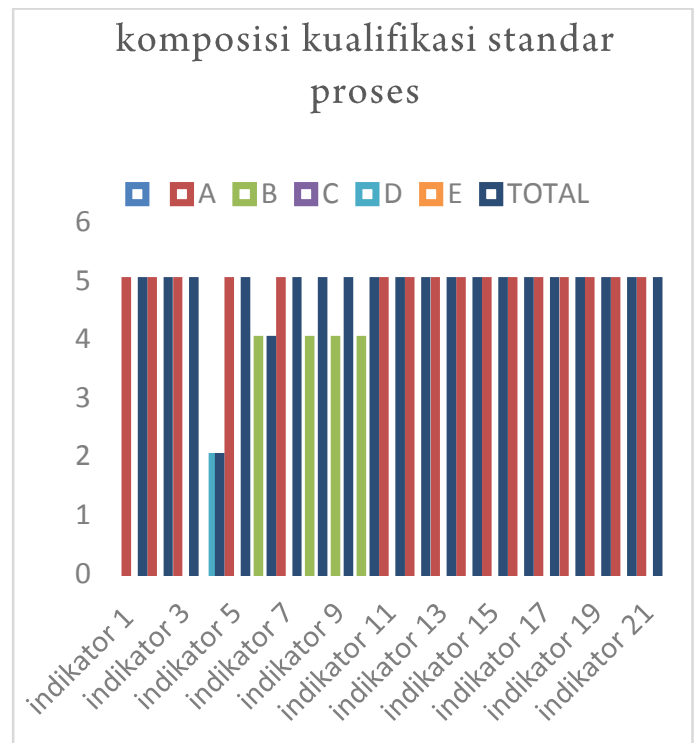

Gambar 1. Profil Ketercapaian Indikator Standar Proses

Gambar 1 menunjukkan profil ketercapaian indikator standar proses pada SMPN 1 Cisaat. Dari 21 indikator, ada 5 indikator yang perolehan skor kurang dari 5, yaitu indicator 4 dan $6,8,9,10$. Indikator 4 dan 6, 8, 9, 10 pada standar proses ini menyangkut aspek jumlah siswa maksimal dalam satu rombongan belajar (36 orang). Sedangkan indiaktor 6 menyangkut pengelolaan kelas yang hanya melibatkan 10-11 kriteria guru dalam melakukan pengelolaan kelas yang baik (keadaan ideal sebanyak 12 kriteria).

Berdasarkan analisis data di atas, diketahui bahwa indikator yang belum mencapai skor optimal adalah jumlah peserta didik dalam satu kelas 
(rombongan belajar). Seperti halnya disimpulkan oleh Sule (2016) bahwa jumlah siswa dalam satu rombongan belajar berpengaruh kepada keberhasilan belajar mereka. Demikian pula menurut Adeyela (2000) bahwa Jumlah peserta didik yang besar dalam satu kelas akan berpengaruh kepada hasil pembelajaran. Senada dengan kedua hasil penelitian di atas, Time (2003) mengkaji bahwa jumlah siswa dalam satu kelas akan berpengaruh kepada kualitas layanan pembelajaran.

Indikator yang belum optimal dicapai oleh sekolah MA Adzuriyatus Solihin adalah indikator keenam yaitu menyangkut kualitas pengelolaan kelas oleh guru. Seperti halnya disimpulkan oleh Dicke et al (2015) bahwa kemampuan dalam pengelolaan kelas akan berpengaruh kepada kemampuan pedagogic tenaga pendidikan pemula. Demikilan pula menurut Wolff (2017) menyimpulan bahwa kemampuan guru dalam pengelolaan kelas mempengaruhi perlaku dan disiplin peserta didik. Berkaitan dengan upaya meningkatkan kemampuan pengelolaan kelas, Piwowar et al (2013) memberikan solusi bahwa untuk meningkatkan kemampuan pengelolaan kelas diperlukan pelatihan khusus.

Berdasarkan hasil analisis data dan beberapa hasil penelitian tentang jumlah peserta didik dalam kelas dan pengelolaan kelas, maka dapat dilakukan upaya-upaya yang berkaitan dengan kebijakan maupun teknik pedagogik. Jumlah peserta didik dalam satu kelas (rombongan belajar) hendaknya dibatasi, yaitu maksimal 36. Jumlah peserta didik dalam satu kelas sangat berpengaruh terhadap kualitas pelayanan pembelajaran dan hasil belajar. Demikian pula untuk meningkatkan kemampuan pengelolaan kelas, setiap tenaga pendidik harus mendapatkan pelatihan khusus.

\section{Komposisi Kualifikasi Standar Proses, Analisis Kesulitan, Ketercapaian Standar Proses}

Berdasarkan deskripsi data, MA Adzuriyatus Solihin Ciparay Bandung dalam melaksanakan proses pembelajaran bahwa belum semua guru mampu mengaplikasikan model pembelajaran. Masih bermasalah dalam penguasaan dan pemahaman terhadap RPP yang dibuat oleh masingmasing guru. Kemudian masih kurangnya kompetensi dalam pembelajaran yang disebabkan masih pasifnya guru dan tidak konsisten dalam mengaplikasikan rencana pembelajaran. Dalam penggunaan model pembelajaran yang sesuai dengan karakteristik dan mata pembelajaran yang 
melakukan $81 \%$ - 90\% guru menggunakan model yang sesuai. karena ada salah satu guru yang belum bisa menerapkan model pembelajaran dan belum menjadi suatu kebiasaan. indikator 9 menyangkut guru menggunakan metode pembelajaran sesuai dengan karakteristik siswa dan mata pelajaran hanya berkisar $81 \%-90 \%$ guru yang menggunakan metode yang sesuai dan indikator. Jumlah skor total yang dicapai pada standar proses di atas adalah 96 dari skor maksimal 105. Sehingga secara keseluruhan capaian standar proses adalah $91,42 \%$.

Berdasarkan analisis data di atas, diketahui bahwa indikator yang belum mencapai skor optimal adalah penggunaan model pembelajaran di kelas sesuai karakteristik siswa seperti yang disimpulkan oleh Suryadi Budi (2013) terdapat pengaruh motivasi signifikan terhadap motivasi belajar siswa dengan menggunakan metode pembelajaran. Demikian pula menurut Akhmad (2008) metode pembelajaran dapat diartikan sebagai cara yang digunakan untuk mengimplementasikan rencana yang sudah disusun dalam bentuk kegiatan nyata dan praktis untuk mencapai tujuan pembelajaran. Demikian pula menurut Muhammad Chomsi (2012) mengatakan bahwa dengan menggunakan metode pada pembelajaran di kelas mampu meningkatkan aktifitas belajar.

Indikator yang belum optimal dicapai oleh sekolah MA Adzuriyatus Solihin adalah indikator kesembilan yaitu menyangkut kualitas pengelolaan kelas oleh guru yaitu mengenai model pembelajaran di kelas, menurut Eko Putro (2009) yaitu penilaian terhadap implementasi program pembelajaran berusaha untuk menilai seberapa tinggi nilai kualitas pembelajaran yang dilaksanakan oleh guru terutama pada penerapan model pembelajaran dikelas. Demikian pula menurut Ridwan Abdullah (2014) mengatakan bahwa pembelajaran yang saintifik yang terdapat dalam kurikulum 2013 yang mencangkup lima aktifitas belajar salah satunya adalah dengan menggunakan pendekatan saintifik atau model. Demikian pula menurut Muhammad (2015), Untuk membelajarkan siswa sesuai dengan cara-gaya belajar mereka sehingga tujuan pembelajaran dapat dicapai dengan optimal harus menggunakan berbagai model pembelajaran.

Berdasarkan hasil analisis data dan beberapa hasil penelitian tentang metode pembelajaran di kelas dan model, maka dapat dilakukan upayaupaya yang berkaitan dengan kebijakan maupun pelatihan terhadap 
penerapan metode dan model di kelas dan penyusunan RPP yang baik. Metode dalam pembelajaran di kelas sangat berpengaruh pada pencapaian pembelajaran di kelas. Demikian juga dengan model pembelajaran mampu mencapai pembelajaran dengan optimal melalui model pembelajaran. Oleh karena itu untuk meningkatkan hasil belajar siswa pengelolaan penerapan pembelajaran sesuai dengan metode dan model guru harus mendapatkan pelatihan khusus untuk mencapai pembelajaran.

\section{Alternatif Solusi Menjawab Tantangan}

Berdasarkan hasil data ketercapaian ini, penulis memberikan solusi untuk belum tercapainya indikator dengan belum tercapainya pada pembelajaran di kelas dengan jumlah siswa maksimum 36 orang per kelas. Namun jumlah siswa per kelas baru mencapai 20 orang rata-rata per kelas. Permendikbud telah menetapkan standar yang seharusnya diikuti oleh sekolah, salah satunya standar proses yang tertuang dalam Permendikbud No. 65 tahun 2013, di mana disebutkan bahwa penyusunan perencanaan dibutuhkan pedoman sehingga perencanaan proses pembelajaran berfungsi sebagaimana mestinya. Dan ada beberapa guru di sekolah ini yang Masih ada beberapa guru yang belum 12 kriteria dalam hal pengaturan suara dan tempat. Kesulitannya yaitu dalam mengatur intonasi ketika memberi penjelasan, dikarenakan masih ada guru yang kadang belum siap atau memahami betul RPP dan materi akhirnya terkesan tidak pas ketika menyampaikan. Selain itu dalam pengaturan tempat duduk siswa, cenderung statis tidak berubah-ubah posisi Sehingga terkesan pasif tidak aktif dalam mengelola kelas. Untuk mengatasi hal tersebut kepala sekolah membuat rencana supervisi akademik. Langkah-langkahnya meliputi:

(1) Perencanaan dengan mengidentifikasi permasalahan yang terjadi.

(2) Mengumpulkan data dengan kunjungan ketika guru bersangkutan mengajar atau pertemuan khusus dengan guru bersangkutan.

(3) Memberikan pembinaan guru dan sharing tentang pembelajaran yang efektif dan lebih baik.

(4) Evaluasi dari hasil pelaksanaan supervisi yang dilakukan kepala sekolah.

(5) tindak lanjut. Dilaksanakan minimal setiap 1 semester sekali.

Indikator berikutnya yang belum memenuhi indikator adalah belum semua guru mampu mengaplikasikan model pembelajaran dalam setiap 
pembelajaran. Masih bermasalah dalam penguasaan dan pemahaman terhadap RPP yang dibuat oleh masing-masing guru. Kemudian masih kurangnya kompetensi dalam pembelajaran yang disebabkan masih pasifnya guru dan tidak konsisten dalam mengaplikasikan rencana pembelajaran. Kepala sekolah melakukan supervisi pembelajaran dan pembinaan profesi guru di sekolah. Langkah-langlah:

(1) Mengadakan kunjungan kelas

(2) Membimbing guru tentang cara mempelajari pribadi dan kondisi siwa di kelas.

(3) Membimbing guru dalam hal yang berhubungan dengan pelaksanaan kurikulum

(4) Melakukan pembinaan secara umum terhadap guru mata pelajaran tertentu. Pelaksanaannya bisa per catur wulan sekali, sebulan sekali, ataupun 1 semester sekali.

Indikator berikutnya yaitu dari hasil supervisi kepala sekolah ada 15 guru yang melakukan metode pembelajaran yang sesuai. Kesulitannya adalah pemahaman yang kurang matang dalam menyusun perangkat dan rencana pembelajaran. Solusinya yaitu melakukan supervisi dan tindak lanjut supervisi. Langkah-langkah:

(1) Evaluasi proses pembelajaran dari hasil supervisi.

(2) Membuat program tindak lanjut dari hasil supervisi.

(3) Melakukan pembinaan kepada guru secara komprehensif.

(4) Melakukan penilaian kinerja guru.

(5) Pelaksanaan Proses tindak lanjut supervisi dilaksanakan setiap sesudah adanya evaluasi proses pembelajaran dari kepala sekolah.

Standar Proses adalah kriteria mengenai pelaksanaan pembelajaran pada satuan pendidikan untuk mencapai Standar Kompetensi Lulusan. Standar Proses dikembangkan mengacu pada Standar Kompetensi Lulusan dan Standar Isi yang telah ditetapkan sesuai dengan ketentuan dalam Peraturan Pemerintah Nomor 19 Tahun 2005 tentang Standar Nasional Pendidikan sebagaimana telah diubah dengan Peraturan Pemerintah Nomor 32 Tahun 2013 tentang Perubahan atas Peraturan Pemerintah Nomor 19 Tahun 2005 tentang Standar Nasional Pendidikan.

Proses Pembelajaran pada satuan pendidikan diselenggarakan secara interaktif, inspiratif, menyenangkan, menantang, memotivasi peserta didik 
untuk berpartisipasi aktif, serta memberikan ruang yang cukup bagi prakarsa, kreativitas, dan kemandirian sesuai dengan bakat, minat, dan perkembangan fisik serta psikologis peserta didik. Untuk itu setiap satuan pendidikan melakukan perencanaan pembelajaran, pelaksanaan proses pembelajaran serta penilaian proses pembelajaran untuk meningkatkan efisiensi dan efektivitas ketercapaian kompetensi lulusan.

Sebagaimana Newman (Majid, 2008), mengemukakan bahwa, perencanaan pembelajaran adalah proses memilih, menetapkan dan mengembangkan pendekatan, metode dan tekhnik pembelajaran, menawarkan bahan ajar, dan menyediakan pengalaman belajar yang bermakna serta mengukur tingkat keberhasilan proses pembelajaran dalam mencapai hasil pembelajaran. Hasil penelitian secara umum menunjukkan bahwa pencapaian pelaksanaan perencanaan pembelajaran yang dilakukan oleh guru rata-rata tercapai dengan kriteria "Sangat Efektif". Hal tersebut berarti pelaksanaan perencanaan pembelajaran sudah sesuai dengan standar proses pembelajaran. Hampir seluruh guru sudah menyusun rencana pembelajaran dengan maksimal.

Berdasarkan permasalahan tersebut, maka adapun solusi yang ditawarkan penulis dalam membantu guru-guru yang memiliki kesulitan dalam menciptakan pembelajaran yang menarik adalah melalui penerapan media "MBS" (minat, bakat siswa). Media minat, bakat siswa (MBS) merupakan suatu langkah strategis yang dapat dilakukan oleh guru untuk menciptakan pembelajaran yang inovatif dan menarik. Pada Media minat, bakat siswa (MBS) ini siswa dapat menjadikan media pembelajarannya sesuai keinginannya. Untuk menerapkan Media ini guru harus menggunakan Student Centered learning atau strategi pembelajaran yang berpusat pada siswa karena dalam proses penerapan pembelajaran menggunakan media MBS siswalah yang aktif untuk membuat, dan merancang sendiri media yang dapat ia gunakan selama proses pembelajaran. Adanya penggunaan Media MBS sebagai sarana untuk mengoptimalkan pembelajaran yang dilakukan oleh guru. Pendapat serupa dikemukakan oleh (Sapto Haryoko, 2009: 9) bahwa berdasarkan hasil pengujian hipotesis yang menyatakan bahwa pembelajaran menggunakan media lebih baik dibanding dengan pembelajaran melalui pendekatan konvensional". 


\section{PENUTUP}

Pelaksanaan standar proses disekolah MA Dzurriyatus Solihin belum memenuhi kriteria yang ditetapkan Permendikbud nomor 65 tahun 2013 , baik dari komponen perencanaan, pelaksanaan, penerapan model pembelajaran, penerapan metode pembelajaran dan penggunaan sumber belajar sesuai karakteristik siswa.

Berdasarkan Grafik dan anaisis hasil penelitian yang telah dilakukan pada MA Addzuriyatus Sholihin dan penelitian sejenis maka diperoleh informasi tentang kelemahan yang dialami oleh beberapa faktor yang belum tercapainya indikator, yaitu terdapat pada Grafik ada indikator terendah ke-2 dan ke 6, 8, 9, 10. Berdasarkan hasil penelitian di MA Addzuriyat Solihin pada indikator nomor 6 bahwa hanya $81 \%$ - 90\% guru yang menggunakan model yang sesuai. Pada indikator 8 hanya $81 \%$ - 90\% guru yang menggunakan media yang sesuai. Pada indikator 9 hanya $81 \%$ - 90\% guru menggunakan sumber belajar yang sesuai. Pada indikator 10 ha ya $81 \%$ - 90\% menggunakan pendekatan yang sesuai.

Berdasarkan temuan tersebut, maka disarankan bagi kepala sekolah sebaiknya menyelenggarakan pengawasan dan evaluasi pembelajaran secara rutin, dengan perencanaan dan pemetaan terlebih dahulu, sehingga dapat meningkatkan peran guru melaksanakan proses pembelajaran. Kepala sekolah perlu menyelenggarakan pelatihan dan diskusi rutin untuk perbaikan pembelajaran agar guru dapat menyelesaikan permasalahan ketika proses pembelajaran berlangsung. Bagi guru diharapkan secara rutin dapat mengevaluasi perencanaan pembelajaran yang disesuaikan dengan kondisi peserta didik dan karakterisktik materi pelajaran.

\section{DAFTAR PUSTAKA}

Arikunto, S. 2010. Prosedur Penelitian: Suatu Pendekatan Praktik. Jakarta: Rineka Cipta.

BBC, Ranking Pendidikan Dunia Tahun 2015. Diakses tanggal 20 Februari 2019 pukul 10:26.

Djohar. 2006. Pengembangan Pendidikan Nasional Menyongsong Masa Depan. Yogyakarta : Grafika Indah. 
Menteri Pendidikan Nasional Republik Indonesia. 2007. Peraturan Menteri Pendidikan Nasional Republik Indonesia Nomor 41 Tahun 2007 tentang Standar Proses untuk Satuan Pendidikan Dasar dan menengah.

Fathurrohman, Muhammad. 2015. Model-Model Pembelajaran. Jogjakarta: ArRuzz Media.

Nyoman Dantes, Supervisi Akademik dalam Kaitannya dengan Penjaminan Mutu Pendidikan. Makalah disampaikan pada Workshop Penjaminan Mutu para Kepala Sekolah se Kabupaten Karangasem, 28 Oktober 2008.

Sugiyono. 2014. Metode Penelitian Pendidikan Pendekatan Kuantitatif, Kualitatif, Dan $R \& D$. Bandung: Alfabeta.

Sill Desta, Tinjauan Segi Kualitas dan Kuantitas Problematika Pendidikan di Indonesia. Diakses tanggal 20 Februari 2019 pukul 10:08.

Wina Sanjaya. 2001. Strategi Pembelajaran Berorientasi Standar Proses Pendidikan. Jakarta: Kencana.

Sule, Samuel Sardauna. 2016. "Effects Of Assignment And Class Size On Secondary School Students'achievement In Mathematics." ATBU Journal of Science, Technology and Education 4, no. 2.

Dicke, Theresa, Jill Elling. 2015. Annett Schmeck, and Detlev Leutner. "Reducing reality shock: The effects of classroom management skills training on beginning teachers." Teaching and Teacher Education 48.

Time, Prime. 2003. "State wide class size studies". Review of Educational Research 73.

Wolff, Charlotte E., Halszka Jarodzka, and Henny PA Boshuizen. 2017. "See and tell: Differences between expert and novice teachers' interpretations of problematic classroom management events." Teaching and Teacher Education 66.

Widoyoko, Eko Putro. 2009. Evaluasi program pembelajaran. Yogyakarta: Pustaka Pelajar.

Rakhmadhani, Nuzul; Yamtinah, Sri; Utomo, Suryadi Budi. 2013. Pengaruh penggunaan metode teams games tournaments berbantuan media teka-teki silang dan ular tangga dengan motivasi belajar terhadap prestasi siswa pada 
materi koloid kelas XI SMA Negeri 1 Simo tahun pelajaran 2011/2012. Jurnal Pendidikan Kimia, 2.4.

Sudrajat, Akhmad. 2008. Pengertian pendekatan, strategi, metode, teknik, taktik, dan model pembelajaran. Online)(http://smacepiring. wordpress. com),

Imaduddin, Muhammad Chomsi; Utomo, Unggul Haryanto Nur. 2012. Efektifitas Metode Mind Mapping untuk Meningkatkan Prestasi Belajar Fisika pada Siswa Kelas VIII. Humanitas: Jurnal Psikologi Indonesia, 9.1. 